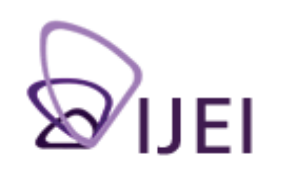

International Journal for Educational Integrity

\title{
Constructing the crisis: Audience perceptions of for-profit education and institutional integrity in the closure of Dana College
}

\author{
Amanda M. Sladek \\ University of Kansas \\ asladek@ku.edu
}

Keywords: for-profit education, corporatisation, institutional integrity, audience, Dana College, Higher Learning Commission

\begin{abstract}
For-profit education is playing an increasingly important role in the educational landscape, with more and more students enrolling in these institutions. However, many within and outside higher education decry the 'corporatisation' of education, fearing that profit motives are beginning to override concerns of institutional and intellectual integrity. This article examines how narratives surrounding for-profit education shape public perception of institutional integrity and how these narratives are co-constructed by their audiences by highlighting as a case study Dana College, a small nonprofit liberal arts college that suspended operations in June 2010 after an unsuccessful attempt to transfer ownership to a for-profit entity. This case study illustrates how failing to account for conflicting, audience-dependent perceptions of educational integrity in an evolving educational landscape can jeopardise the future of higher education.
\end{abstract}

\section{Introduction and background}

The issue of for-profit higher education has long been a contentious one. Students in the United States (US) have been enrolling in for-profit institutions at a rapidly accelerating rate. According to a report released by the US Senate Committee on Health, Education, Labor, and Pensions (2012), "Between 2004 and 2010, the number of Associate degrees awarded by for-profit colleges increased 77 percent and the number of Bachelor's degrees awarded increased 136 percent" (p. 3). As these institutions recruit more and more students, the issue of for-profit education has been met with considerable scepticism. Kim R. Sawyer, Jackie Johnson, and Mark Holub (2009), analysing the phenomenon they call the "corporatization" (p. 11) of universities (a phenomenon which includes, but is not limited to, for-profit education), note that within the new corporate university' structure, educational and administrative decisions are often motivated by profit-driven concerns, rather than "intangible values" (p. 11) such as academic integrity and the quest for truth. The previously cited US Senate report expresses concern that for-profit colleges and universities are frequently not held to the same federal accountability standards as their nonprofit counterparts, and that the student retention rate at these for-profit entities is generally lower (2012). These issues have caused many in the field of higher education to question the integrity of these colleges and universities and, by extension, for-profit education in general.

Certainly, the integration of business values into the realm of academia makes many in higher education feel uneasy. Yet, not all in higher education take such a negative

The International Journal for Educational Integrity is available online at:

http://www.ojs.unisa.edu.au/journals/index.php//JEI/

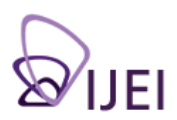


view of for-profit education. Martha J. Kanter, former Under Secretary of Education under President Barack Obama, has praised for-profit colleges in their efforts to reach out to nontraditional students and continuing learners with their focus on career-based learning, telling attendees at a Career College Association investor meeting that "All of higher education can learn some lessons from you" (Blumenstyk, 2009). The fact that students are turning to these institutions in increasing numbers indicates that many are embracing this new model of higher education. In an unstable global economy, there is a greater demand for the career-based education that for-profit colleges often provide. Sawyer et al. (2009), though they take a generally negative view of corporatised education, acknowledge that the "old university" was "unresponsive to government needs to educate more students to higher levels [and] slow in responding to the demands of students for market-related courses" (p. 12). As with most matters in education, the debate is complex and multifaceted. The issue is rendered even more complex when one considers the perspectives of multiple groups, such as students, investors, and members of surrounding communities, who are directly affected by policy decisions and attitudes regarding for-profit education. These groups have different, often conflicting perspectives of institutional integrity and the values of academia. These contradictory viewpoints and the rhetoric they employ can have tangible and even disastrous consequences for institutions that cannot adapt to the evolving educational landscape.

Such was the case with Dana College, a small nonprofit liberal arts college located in the rural community of Blair, Nebraska. After years of financial struggle and an unsuccessful attempt at transferring ownership to a for-profit entity, the School suspended operations in June 2010. In the media coverage surrounding the College's attempted sale and eventual closure, questions of Dana's history, mission, and legacy were thrown into a dialogue about a changing educational landscape to which the College had heretofore failed to adapt. Participants in this dialogue included government entities, business insiders, faculty and student voices, as well as local and national news outlets. Looking at the rhetoric surrounding Dana's closure, one can observe how, as different entities framed the event for different audiences, different narratives emerged. Examining the local and national media coverage of the Dana College story through the lens of audience theory, it becomes clear that the narratives constructed around the event were shaped as much by audience as the event itself. Each of these narratives takes a slightly different view of the institutional integrity of for-profit education generally and Dana College specifically. This case study illustrates how the idea of institutional integrity is audience- and contextdependent, and how, if we don't recognise the value in these competing perspectives and use them to frame a meaningful dialogue about the future of academia, the conflict between differing ideas of educational integrity can jeopardise the futures of higher learning institutions.

\section{The case of Dana College}

On June 30, 2010, Dana College announced it would be closing its doors. The School, founded by Danish immigrants in 1884, had been in operation for 126 years. Various sources provide different estimates of the size of the student population at the time of the School's closure, ranging from 550 students (Hansen, 2010) to 637 (Epstein, 2012) ${ }^{1}$. Dana had been struggling financially since 2005; at the time of its closure, its endowment stood at only $\$ 1$ million (Epstein, 2012). Several months prior to Dana's closure, a group of independent investors expressed interest in purchasing the nonprofit liberal arts school and turning it into a for-profit college. This group, known as the Dana Education Corporation (DEC), intended to take ownership of the School in the fall of 2010. However, Dana's application to change ownership was rejected by the Higher Learning Commission (HLC), the accrediting agency responsible for overseeing many colleges and universities throughout the Midwestern US. 
The HLC cited the DEC's inexperience, lack of funding, and its "inability to show that the college's 'institutional and educational integrity' would be protected" (among other issues) as the reasons behind its decision (Abourezk, 2010). Yet, many people both within and outside the Dana community attributed the decision to the US government's increasing scepticism of for-profit colleges. As detailed by Charles Huckabee (2010), the HLC's decision was handed down two weeks after then-HLC President Sylvia Manning testified before the United States House of Representatives on the topic of accrediting for-profit universities. Congress criticised Manning and the $\mathrm{HLC}$ for its earlier accreditation of the for-profit American InterContinental University. The following week, Illinois Senator Richard J. Durbin publicly decried the practice of for-profit educational institutions purchasing nonprofit colleges in order to gain accreditation. Dana's former Vice President for Institutional Advancement, Jeremy Bouman, was quoted in the Wall Street Journal, saying Dana was "collateral damage" and that "There was never a chance to be successful because of the political scrutiny" surrounding for-profit education (Etter, 2010). Officials from nearby universities voiced their disagreement with the decision, as did local politicians such as Nebraska Governor Dave Heineman, Senators Ben Nelson and Mike Johanns, and former Senator (and current United States Secretary of Defense) Chuck Hagel (Epstein, 2012).

Because Dana was a local institution and its closure affected many in Blair and the surrounding area, the incident soon became a top story in local news. National publications such as the Wall Street Journal, The Chronicle of Higher Education, and Inside Higher Ed also covered the story for a national audience. Each of these entities, local and national, was tasked with framing the event in a way that their audience would find appropriate and relevant. This audience-based rhetorical framing created multiple narratives within different audience communities, resulting in different conceptions of educational integrity and its role in the Dana decision. The rhetorical strategies employed by the authors of these narratives reflect various attitudes toward for-profit education and the future of higher education as a whole. If the modern university is to adapt to a changing educational landscape, it is crucial to examine the ways in which corporatised education is being framed not only in the field of education, but in popular media outlets as well-the kind likely to be accessed by students, potential donors, and others on the periphery of academia. Recognising that these diverse participants in the dialogue surrounding higher education will have different definitions of educational integrity, and that these definitions are partially dependent on situation and narrative, can help those of us in academia participate in a more informed and meaningful dialogue about the future of higher education. This involves examining not only the tone and content of the narratives themselves, but the complex role audience plays in the consumption and production of these narratives.

\section{Media, audience, and mutual construction of meaning}

Recent theories in the field of Rhetoric and Composition have complicated the notion of the audience as a passive recipient of an author's or orator's message. Rather, the audience is an active participant in shaping the meaning of discourse. Lisa Ede and Andrea Lunsford (1984) distinguish between two schools of thought on audience. The first, which they term "audience addressed", sees the audience as a "concrete reality" whose attitudes and expectations must be accounted for in the composing process ( $p$. 156). In this case, this would include the physical readers of a news article about Dana's closure. The other, referred to as "audience invoked," views the audience as a fictionalised construct created by the writer through "semantic and syntactic . . cues which help to define the role or roles the writer wishes the reader to adopt in responding to the text" (p. 160). This would include not the physical readers of a newspaper article, but the vision of this audience, or even an idealised audience, that the author holds in his/her head as he/she composes. Though these schools of thought are in many ways opposing, Ede and Lunsford conclude that neither alone is sufficient to explain the complex and evolving roles assumed by audiences in specific 
rhetorical situations: "The most complete understanding of audience thus involves a synthesis of the perspectives we have termed audience addressed, with its focus on the reader, and audience invoked, with its focus on the writer" (p. 167). Both perspectives are at work in a rhetorical situation, and their relative importance evolves in different situations and even within the same situation.

James E. Porter (1992) complicates this dichotomy further by acknowledging not only the rhetorical situation in which a writer or orator communicates with an audience, but the larger social context in which these roles shift and even merge. He proposes a "poststructuralist" view of audience that draws on John Swales's idea of discourse communities, which Swales (1990) defines as "sociorhetorical networks that form in order to work toward sets of common goals" and use various methods of communication to do so (p. 9). In the particular case of Dana College, it is helpful to draw on the social constructionist notion of discourse community, which emphasises a priori communities such as professional or academic disciplines. In these cases, "it is assumed that the social field exists prior to ... texts and brings these texts into existence" (Porter, 1992, p. 87). This is clearly the case with Dana College, a preestablished academic community whose existence predates the discourse being examined here and whose closure prompted said discourse. It is also true of the field of higher education in general, as it is an academic discipline with a set of common goals and methods of communication.

Porter's notion of discourse community has interesting implications for audience and authorship. He posits that "the discourse community is as much the author as the audience... [and] from the social perspective the discourse community is at once the producer and consumer of its own discourse" (p. 84). Rather than a passive recipient of information, the discourse community is an active participant. Community members are as important as the author in determining the meaning of a text, as they have a hand in creating the discourse of the community by not only authoring texts, but interpreting and deriving meaning from a text. One can see this in the rhetoric surrounding the closure of Dana College, in which the discourse community of Dana College and the larger academic community conflict, overlap and attempt to renegotiate the concept of academic integrity in a corporatised educational climate.

This active audience role is further emphasised in a recent strain of scholarship that distinguishes between audiences and "publics". Sonia Livingstone (2005) explains this differentiation, stating that although both audiences and publics may be included in a common forum or discourse, ". . . 'public' implies an orientation to collective and consensual action ... audiences are denigrated as trivial, passive, individualised, while publics are valued as active, critically engaged and politically significant" (pp. 17 -18). Livingstone goes on to argue that the distinction between audiences and publics is becoming increasingly difficult to draw as the media expands the role of the audience. This public audience aligns somewhat with Porter's conception of discourse community: both labels imply an active, participatory role in meaning-making through collective action. This becomes especially salient in the coverage of Dana's closure, as much of the rhetoric involves some sort of call to action, either to save Dana College, protest the HLC's decision, or protect academia from the encroachment of for-profit interests.

As Livingstone suggests, the media plays a crucial role in the formation and development of audiences and publics. Angela M. Lee (2013), in her study of the motivations behind television news consumption, notes that individuals often watch television news "for social values or interpersonal utilities" (p. 305). Though Lee focuses on the individual motivation behind news consumption rather than viewers' role as audience, this "social-motivated news consumption" can create or expand a discourse community or public. For example, the news coverage of the 2012 murder of unarmed teenager Trayvon Martin and the acquittal of his shooter, George Zimmerman, created a community of Martin supporters that spanned the US. Though 
many Americans undoubtedly followed the story for "information-motivated" reasons (Lee, 2013, p. 303), social motivations created a public around the common goal of protesting the Zimmerman verdict and the perceived racism in the American justice system. Media personalities such as radio host Michael Baisden and Current TV host Jennifer Granholm even signaled identification with this community by encouraging their audiences to post social media photos of themselves wearing hoodies, as Martin was on the night he was killed (Eversley, 2012), further demonstrating the connection between news media, audience, and discourse community. This connection between media and audience can also be seen in local news coverage of the closure of Dana College.

\section{"Everyone is devastated": Community implications in local news coverage}

Because Blair is a small, rural community, most local coverage of the closure of Dana College came out of nearby cities such as Omaha and Lincoln. The notion of community (both the Dana College faculty/staff/student community and the larger Blair community) was prominently featured in much of the local coverage of Dana's closure. However, with Dana College itself no longer able to anchor this discourse community, the boundaries of the community became much more nebulous (or, to borrow Porter's term, "fuzzy"). Though the physical institution itself was no longer able to anchor and define the boundaries of this discourse community, the community continued to exist in a different form. As the common goal of the discourse community shifted from making sure the College ran smoothly to figuring out the next steps in providing support to the people directly affected by the closure, the new discourse community came to include socially motivated viewers who empathised with those affected by the School's closure and who followed the story in the local news. Thus, it became a true "discourse community [that] cuts across sociological or institutional boundaries" (Porter, 1992, p. 106, emphasis in original). This process was aided by the narrative of the closure created by local news media, and one can observe the beginning of this process in one of the first local television news broadcasts reporting the story.

This piece, aired by Omaha's local ABC affiliate, KETV, was originally broadcast on the evening of June 30,2010, the day that Dana's closure was announced. The newscast covers basic information about Dana's proposed sale to the DEC, the decision handed down by the HLC, and the reactions of important people in the story. The Dana community is referenced almost immediately, with one of the anchors introducing the story by asking the question, "So, what does this mean for all of those students set to go to class in the fall?" (KETV, 2010). With this statement, the story is placed in an emotional, human context before any detailed information is conveyed, indicating that the people affected by the closure will play a central role in KETV's coverage of the incident. The news anchors invoke an emotionally invested audience from the very beginning, drawing on shared values (concern for the students) to invoke a discourse community.

Throughout the news clip, the HLC is positioned as the adversary, and Dana is portrayed as the entity possessing greater institutional integrity (which is perhaps not surprising, as the College had a positive reputation in the local community). This positioning is accomplished primarily through the use of quotes from officials involved in the administration of the former Dana College. Reporter Adrian Whitsett quotes Dana College Board Chairman Dennis Gethmann, saying, "We are devastated that despite meeting all requests and assiduously working to meet all requirements, the HLC's decision does not allow for Dana's continuing operation" (KETV, 2010). He also quotes DEC President Raj Kaji, saying, "We are deeply saddened by the impact this will have on the Dana community, the faculty and staff, the community of Blair, the state of Nebraska and most importantly the hundreds of students who will be displaced by this decision" (KETV, 2010). These quotes specifically invoke the Dana community as an audience and can even be seen as the invocation of a public 
concerned with the injustice inflicted on Dana College and the Blair community. The projected values of the HLC do not align with those of the Dana community and the HLC is therefore placed firmly outside the community. Gethmann strongly implies that the HLC demonstrated a lack of integrity by denying Dana's request to change ownership, while Kaji relies more on emotionally laden language to emphasise the unjustness of the HLC's decision.

The newscast also uses voices from within the Dana student community to invoke a socially-motivated public audience beyond those directly affiliated with the institution. At the end of the newscast, Whitsett paraphrases the words of a Dana student, saying, "Jenna Peyton says everyone is devastated, and the close-knit relationships between students and professors are broken. Now, Peyton has to find another small school, and she has no idea if her scholarship money from Dana will transfer" (KETV, 2010). Whitsett, in interviewing and paraphrasing Peyton, invites a real (or "addressed") member of the Dana community to invoke the community as a whole. By bringing in the voice of an actual Dana student on the day of the School's closure, all viewers are essentially invited to experience the closure along with the Dana community-a community explicitly referenced and identified as "close-knit". In this and other local news artefacts produced in the weeks following Dana's closure, one can see in the invoked audience not only the creation of a broader discourse community of Dana supporters, but the invocation of a public tasked with the goal of supporting Dana College.

In the days following Dana's closure, local print news followed the community's attempt to persuade the HLC to reverse its decision. An article in the Omaha WorldHerald, Omaha's largest newspaper, details the efforts of School officials and local politicians to "save" Dana. This article also quotes Gethmann, who states, "I think there are no illusions that we are fighting an uphill battle here ... We feel like it's something we need to do" (Hansen, 2010). By framing the Dana College saga as a battle that must be fought, and one that is unlikely to succeed, the article invokes a more involved public audience than the emotionally-oriented newscast. The decision handed down by the HLC is treated as unjust, and several of the reasons the HLC gave in its decision (such as the inexperience of the DEC) are refuted. In this article, Governor Dave Heineman states that Nebraska Attorney General Jon Bruning would "investigate the [HLC's] accreditation practices" (Hansen, 2010), explicitly calling into question the integrity of the accrediting institution. Bruning's response is "active, critically engaged and politically significant" (Livingstone, 2005, p. 18) and therefore characteristic of a public audience. This sort of call to action and invocation of a public was not unusual in local news coverage of Dana's closure.

In much of the local news coverage of the incident, the reasoning behind the HLC's decision either remains unclear (as in the newscast) or is portrayed as unjust (as in the newspaper article), casting doubt upon the integrity of the HLC and their decisionmaking process. Though these sources do mention that the DEC intended to turn Dana into a for-profit college, this fact is not treated with suspicion. Rather, Dana College and the people involved in the community are positioned as the victims of a shadowy government agency that denied the College its existence. This positioning is largely a reflection of audience considerations. The addressed audience for these publications is the local community, many of whom were either directly or indirectly affected by Dana's closure (or knew somebody who was). As has been demonstrated, the audience was an important co-creator of these texts, which invoke a concerned, socially motivated public who "all saw the [proposed sale] as a lifeline and not a hostile takeover" (Epstein, 2012, p. 91). The Dana College story in this context is primarily a human interest story.

Yet, the case of Dana College had larger implications for higher education nationally and internationally. When national publications began to report on the story, they were tasked with reframing it for an audience that had never before heard of Dana College, 
and for whom Dana College had no previous associations. In the next section, I examine the ways in which the closure of Dana College was repositioned for the larger academic community, which has strikingly different concerns and priorities. The expanded audience of the academic community exerted their influence much in the way the local Dana community did, but to a different end. The result was a strikingly different narrative of the same event, with different implications for the idea of institutional integrity.

\section{Mourning the "Old University": Questions of institutional integrity in educational publications}

Educational publications that covered the closure of Dana College fittingly did so with an eye to the event's implications for higher education in the US. Those in the field of higher education tend to be more suspicious of corporate "intrusion" into academia. This attitude is well illustrated in the previously cited piece by Sawyer et al. (2009), published a year before Dana's closure. The authors draw a distinction between "old universities" and "new, corporate universities," a (as they admit) simplified binary that nonetheless serves to explain what many see to be the decline in educational standards that accompanies the corporatisation of higher education (p. 11). In a corporatised university, it is feared, the loss of financial independence may lead to constraints on scholarship, as academics may be held accountable to the corporation's standards rather than the standards of their fields. Scholars lose control of their academic freedom, resulting in a "decline in academe".

This attitude is also illustrated in many of the articles that detail the closure of Dana College for the larger audience of those involved in American higher education ${ }^{2}$. Scott Jaschik (2010), writing for the popular American education website Inside Higher Ed, criticises local news media for its portrayal of the HLC as the villain that forced Dana College to close. He summarises a statement released by the HLC in response to the public backlash regarding their decision, writing that the HLC warned Dana officials that approval of the sale was not guaranteed. He also notes that the request to transfer ownership did not meet the criteria set forth by the HLC, and that the HLC did not eliminate other possibilities for keeping Dana's doors open. Jaschik then presents the opposing side by interviewing and quoting Kaji, though he emphasises that Kaji would not provide him with the documentation the DEC submitted to the HLC. In contrasting the written, publicly released reasoning behind the HLC's decision with Kaji's unsubstantiated word, Jaschik presents the HLC as being more credible than the DEC. This judgment is not explicitly stated; the audience has to make this connection themselves, mutually co-constructing the meaning of the text.

Jaschik invites this co-construction by invoking an audience likely to trust the HLC's decision. The opening line of the article states: "The accreditor of Dana College wants the world to know that it didn't revoke recognition of the college or order its closure". In a sense, this opening parallels the strategy used by many local media outlets-the opening line invokes a community that is victimised in some way (in this case, by media misrepresentation). Immediately, the reader is primed to see the rest of the article through the HLC's perspective. Jaschik goes on to discuss the emotional tactics employed by the local news media which, read in this light, seem hyperbolic. By the time the reader encounters Kaji's reluctance to produce the documents outlining the DEC's plans for Dana College, the HLC seems like the more just, credible institution. The DEC (and, by extension, for-profit education) is portrayed in a way that would likely cause suspicion in most readers. The fact that this is accomplished without the author explicitly stating an opinion on the subject points to the importance of the audience in constructing the meaning of a text. The audience Jaschik addresses is the readership of Inside Higher Ed (a readership that may be difficult to pin down, since it is an open-access site), but the audience he invokes is the portion of the readership that is sceptical of for-profit education. This article employs some of the same rhetorical strategies as local news coverage of the event; 
yet, because the audience is the national educational community rather than the local community, a drastically different narrative emerges, demonstrating how the common goals and shared values of a discourse community can shape writer-audience interactions.

One can see an interesting tension between local and national audience concerns in an editorial written for The Chronicle of Higher Education, a national publication covering matters related to American colleges and universities. This article was written by Jonathan Brand (2010), president of nearby Doane College. In many ways, Doane College and Dana College were similar: both were small, private, nonprofit, religiously-affiliated liberal arts schools located in Nebraska. As such, they were in many ways part of the same local educational community. In this editorial, Brand attempts to balance his concern for his colleagues at Dana with his role as a college official on a national stage. Though he expresses sympathy for Dana's situation, he uses the situation as an illustration of the dangers of for-profit takeover in education, explaining how for-profit concerns are often in direct conflict with the values of academic inquiry and student-centered administration. Yet, he avoids direct criticism of Dana or the DEC, choosing instead to critique the educational system that contributed to the College's financial distress. He states:

In Nebraska, for example, independent, nonprofit colleges face a particularly challenging financial environment. The state appropriately invests over $\$ 50,000$ in tax money for each degree awarded at the University of Nebraska. But it invests less than $\$ 300$ for each degree awarded by the state's independent colleges-even though they awarded more than 40 percent of all baccalaureate and advanced degrees in the state in 2008-9. (2010)

Brand also points out that the state gives as much money to for-profit universities as they do to nonprofits, despite the fact that nonprofit institutions in Nebraska serve a greater number of students. With this lack of financial support from the state, he concludes, small, private colleges are left vulnerable to corporate interests.

In using Dana College as a case study to critique not only for-profit education, but the political system that allows this form of education to flourish, Brand balances his concern for the Dana College audience with a concern for his larger, national audience. The audience Brand addresses, the readership of The Chronicle of Higher Education, is obviously concerned with issues related to American education.

Because of for-profit education's negative reputation within many academic circles, this invoked audience is likely sceptical of corporatised education. Yet, his invoked audience also clearly includes those familiar with (perhaps even affiliated with) the former Dana College. Despite his implicit agreement with the HLC's decision, he mourns the loss of the College itself. In so doing, he allows for two possible interpretations: those affiliated with Dana College can read this editorial as an elegy for the university and a critique of the state government's lack of support for liberal arts education, while the larger Chronicle readership can read it as a critique of the for -profit model (and, by extension, the DEC). The meaning of the text is partially dependent on the interpretation of two overlapping discourse communities.

Much like in the local news coverage of the incident, Brand positions Dana as a victim of the American educational climate. However, there is an interesting distinction between this piece and local news coverage: rather than Dana being a victim of the HLC's unjust decision, it is a victim of a state government that, through its lack of funding for private colleges, allowed Dana to fall victim to predatory for-profit interests. He states:

The harsh reality that our peers are financially vulnerable to for-profit purchasers or are shutting down entirely serves as a cautionary tale. We need 
to state a clear case to our state governments and other supporters about ... how financial support of the for-profit model can cause unintended damage to independent colleges and the communities they serve. (2010)

In this passage, Dana College is explicitly placed in the role of the "financially vulnerable" victim. The Dana officials who approved the DEC's proposal are almost denied agency. He does not emphasise the fact that, no matter how dire Dana's financial situation was, the decision to propose a transfer of ownership was voluntary. In so doing, he avoids a potentially awkward situation in which he would be forced to criticise the decision made by Dana officials, whom he characterises as his "peers".

It is also interesting to note that, unlike much of the national coverage of Dana's closure, Brand invokes a public audience in this call to action. Yet, he does so in a way that could potentially unite the two factions of his public audience. This strategy, similar to that used in local media coverage, creates the potential for common ground between members of the Dana community who are mourning the loss of their school and the larger educational community who fear the loss of academic values in a corporatised educational landscape. By validating both perspectives, Brand constructs a narrative in which both Dana College and the HLC possess institutional integrity. In fact, he creates a situation in which these overlapping discourse communities could unite behind the common goal of preserving academic integrity and the value of liberal arts education. Porter (1992) notes the potential for the "fuzzy" boundaries of discourse communities to shift as the community's needs evolve. There is no denying that the needs of the educational community are indeed evolving rapidly. However, if academics wish to contribute meaningfully to the course of this evolution, we must engage in critical dialogue with those outside academia-local and national governments, investors, and community members-about what it means to possess academic integrity in the 21 st century.

\section{Conclusions and implications}

The purpose of this article is not to take a stand either for or against for-profit education, nor is it to applaud or protest the HLC's decision to reject Dana College's request to transfer ownership. Rather, it is to situate these larger questions of educational integrity in a real-world, tangible context to illustrate how audience perception of educational integrity can shape and even jeopardise the future of academia. One of the primary advantages of the "old university," as stated by Sawyer et al. (2009), was that, though "financial risks were not negligible ... it was the risk associated with scholarship that was the principal risk of the university" (p. 12). Though there may have been a time when that was true, the rapid rise of for-profit education and the decreasing enrollment numbers seen at many nonprofit universities indicates that this may no longer be the case. This leaves the question: what happens when financial risks do become the "principal risk of the university"?

In the case of Dana itself, an answer may no longer be necessary. Dana College was recently acquired by Midland University, a nearby liberal arts college that took in many former Dana students after the School's closure. Midland intends to turn the former Dana campus into a satellite campus (with plans to open in August 2016), a move that has many in the Blair community hopeful that the town, which struggled economically after Dana's closure, will be reinvigorated (Rickerl, 2013). Though this acquisition is an economic risk for both parties, it has thus far proven less problematic than the DEC's proposed acquisition (perhaps, in part, because Midland University is a nonprofit institution). As Dana College embarks on a possible new chapter, it will enter an educational landscape that has changed drastically even in the four years since its closure. 
This, of course, does not resolve the continuing debate surrounding for-profit education, the solution to which is far from straightforward. In the words of literary theorist and legal scholar Stanley Fish (1980):

... disagreements cannot be resolved by reference to the facts, because the facts emerge only in the context of some point of view. ... Disagreements are not settled by the facts, but are the means by which the facts are settled. Of course, no such settling is final, and in the (almost certain) event that the dispute is opened again, the category of the facts "as they really are" will be reconstituted in still another shape. (pp. 338-339)

The closure of Dana College was one such instance in which the facts surrounding the corporatisation of education had to be reconstituted. Though the actual events leading up to Dana's closure are, in a sense, objectively factual, it is crucial to recognise that the truth always arises through interpretation. Because details about educational matters so often emerge in some form of media narrative, it is difficult to pin down any sort of objective "truth" regarding matters of educational integrity. To make blanket statements about the integrity (or lack thereof) of for-profit education without taking context into account can only contribute so much.

As the structure of the university continues to evolve, we have the opportunity to use the contested and contentious nature of for-profit education as a way to renegotiate what global higher education will look like in the years to come. Though many accounts of Dana's closure position the HLC and the DEC/Dana College as adversaries, a positioning that served its rhetorical purpose when there was still a possibility Dana could be saved, perhaps the disagreement can now serve a more fruitful purpose. Through this disagreement, we can work toward resolving the facts and values that will guide academia into the future. Though these facts are unlikely to ever be universally settled, this disagreement can help individual educators, administrators, and institutions make more conscious, politically aware, and financially realistic decisions regarding the role they will play in the educational system. Though we must certainly proceed with caution when dealing with issues related to the corporatisation of education, we must also be sensitive to the perspectives of local residents, students, and others who may not share the concerns of the educational field. In a changing economy that increasingly values skills-based training over liberal arts and the "old university," perhaps we need to adapt our views of educational integrity, or at least recognise that institutional integrity is dependent on context and audience.

\section{Notes}

1. The author was a student at Dana College from 2007 until the time of its closure in 2010.

2. It is important to note that not all national publications took a negative view of the DEC or for-profit education. See Epstein (2012) for a well-articulated argument against the HLC's decision and Huckabee (2010) for an objective account of the events surrounding Dana's closure.

\section{References}

Abourezk, K. (2010, June 30). Dana College in Blair to close. Lincoln Journal-Star. Retrieved from http://journalstar.com/news/state-and-regional/nebraskal article d83eb3e0-847b-11df-9040-001cc4c03286.html.

Blumenstyk, G. (2009, December 11). High official in Education Department has warm words for for-profit colleges. The Chronicle of Higher Education. Retrieved from http://chronicle.com/article/High-Official-in-Education/49466/. 
Brand, J. (2010, July 7). For-profits buying nonprofits: Salvation or suicide? The Chronicle of Higher Education. Retrieved from http://chronicle.com/article/ Salvation-or-Suicide-/66166/.

Ede, L., \& Lunsford, A. (1984). Audience addressed/audience invoked: The role of audience in composition theory and pedagogy. College Composition and Communication, 35(2), 155-173.

Epstein, R. A. (2012). The role of accreditation commissions in higher education: The troublesome case of Dana College. The University of Chicago Law Review, 79 (1), 83-106.

Etter, L. (2010, September 15). News: A college closes for good as rescue plan is rejected. Wall Street Journal, pp. A.3.

Eversley, M. (2012, March 26). Blacks tap power of social media. USA Today, pp. $03 \mathrm{~A}$.

Fish, S. (1980). Is there a text in this class? The authority of interpretive communities. Cambridge, MA: Harvard University Press.

KETV. [KETV NewsWatch 7]. (2010, July 1). Dana College loses accreditation, must close. Retrieved from https://www.youtube.com/watch?v=0A7vr8Y08QQ.

Lee, A. M. (2013). News audiences revisited: Theorizing the link between audience motivations and news consumption. Journal of Broadcasting and Electronic Media, 57(3), 300-317.

Livingstone, S. (2005). On the relation between audiences and publics. In S. Livingstone (Ed.), Audiences and publics: When cultural engagement matters for the public sphere (pp. 17-42). Portland, OR: Intellect.

Hansen, M. (2010, July 5). One last attempt to save Dana. Omaha World-Herald, pp. $01 \mathrm{~A}$.

Huckabee, C. (2010, July 1). Dana College announces it will close, blaming accreditor's decision against new owners. The Chronicle of Higher Education. Retrieved from http://chronicle.com/article/Dana-College-Announces-ItWill/66110/.

Jaschik, S. (2010, July 12). War of words over Dana. Inside Higher Ed. Retrieved from http://www.insidehighered.com/news/2010/07/12/ dana\#sthash.QFfOmZUQ.dpbs.

Porter, J. E. (1992). Audience and rhetoric. Englewood Cliff, NJ: Prentice Hall.

Rickerl, S. (2013, July 20). Midland picks up the keys to former Dana campus. Fremont Tribune. Retrieved from http://fremonttribune.com/news/local/midlandpicks-up-the-keys-to-former-dana-campus/article 9d6e6cd2-08b2-56cf-838f8b837b4161e4.html.

Sawyer, K. R., Johnson, J., \& Holub, M. (2009). Decline in academe. The International Journal for Educational Integrity, 5(2), 10-28. Retrieved from http:// www.ojs.unisa.edu.au/index.php/IJEl/article/view/610.

Swales, J. (1990). Genre analysis: English in academic and research settings. Cambridge: Cambridge University Press.

United States Congress Senate Committee on Health, Education, Labor, and Pensions. (2012, July 30). For profit higher education: The failure to safeguard the federal investment and ensure student success. Washington, DC: Government Printing Office. (Senate Report 112-37).

\section{About the author}

Amanda M. Sladek is a doctoral student in English at the University of Kansas, with an emphasis in Rhetoric and Composition. Her current research focuses on theories of audience, institutional practices in higher education, World Englishes, and writing knowledge transfer. She is also a graduate assistant on the Collaborative Humanities Redesign Project (CHRP), an interdisciplinary, cross-institutional collaborative project focused on improving humanities course design in the US. 